\title{
Views of postgraduate students regarding research ethics in Turkey ${ }^{1}$
}

\author{
Funda Koçak ${ }^{2}$ \\ Oğuz Özbek ${ }^{3}$
}

\begin{abstract}
This research aimed to examine the level of knowledge of master and doctorate students regarding scientific research ethics and the frequency of scientific deception identification in scientific publications. The research was conducted using descriptive methods. The group under examination consisted of 112 randomly chosen students who pursued their postgraduate degree in physical education and sports fields. The validity and reliability were determined in the framework of this study. Item total correlation and factor analyses were conducted for the construct validity of the assessment tool. The Alpha Coefficient, which was calculated for the scale reliability as .96 , indicated the scale is valid and reliable. The Shapiro-Wilks test was also conducted to determine whether the data were normally distributed. Because the data did not exhibit a normal distribution, a non-parametric Mann-Whitney U test was utilised. "Writing more than one article using the same data", "citing without providing a reference", "reporting findings that are only consistent with expectations", "publishing someone else's ideas without providing references as if they are one's own", "presenting the same research in more than one conference or symposium", and "publishing the same research in more than one journal" are the most non-ethical behaviours perceived in scientific research. All of the participants indicated that "presenting falsified findings of research and publishing someone else's research with own name" represent non-ethical behaviours. According to the research results, "citing without providing a reference" and "writing more than one article using the same data" were the most unethical behaviours identified in scientific studies.
\end{abstract}

Keywords: Falsification; plagiarism; postgraduate student; research ethics.

\section{Introduction}

In addition to facilitating an understanding of the universe, science is a guide that directs many aspects of scientific and social life. Scientists, who are characterised as followers of non-selfseeker information, integrate theoretical advancements into practical projects that concern the entire world (Belsey \& Chadwick, 1998). Scientific studies comprise the intellectual efforts and practices of scientists that aim to identify answers regarding nature, human and society specific questions (TÜBA, 2002). To be accepted as a scientific study, one necessary condition is the suitability of ethics. The word "ethics" has become more of an issue in scientific research similar to many other fields. The main reason that underlies the recent increase in attention regarding ethics is

\footnotetext{
1 This study submitted in 2nd International Social Sciences in Physical Education and Sport Congress, Gazi University

2 Assist. Prof., Ankara University, Faculty of Sport Sciences, Department of Sports Management, fkocak@ankara.edu.tr

3 Assoc. Prof., Ankara University, Faculty of Sport Sciences, Department of Sports Management, oozbek@sports.ankara.edu.tr
} 
the increase in ethical problems or the realisation of increasing problems (Tepe, 2000). Ethics comprises concepts, such as good, bad, and wrong, and represents a system of moral principles, values and standards that defines what is good and bad in individual or group behavioral relations (Hatcher, 2004). Individuals who behave and conduct ethically do not perform transmitted action rules and value standards without questioning; in contrast, these individuals understand and think about these concepts and then turn them into habits to perform the requested good (Pieper, 1999).

Scientific research ethics indicates the application of a higher degree of moral, honesty and clarity principles at all stages, ranging from the identification of a research subject to the postpublication period (Erzan et.al., 2008). In its simplest form, it can be defined as a sub-branch of ethics that concerns the application of the principles of ethics in scientific research (Uluoglu, 2008). Academic research writers should be up to par with defined standards and value criteria, and they should exhibit certain characteristics, such as objectivity, honesty, openness, and professional ethics (Kansu \& Ruacan, 2002). Yannacone (1999) emphasises that academics are responsible for providing neutral information and guidance to society because of their scientist identity. Ethical problems regarding scientific studies and publications have emerged during previous years and have increasingly attracted the interest of researchers in scientific research ethics (Ongun, 2006). Any type of initiative that reduces the value or reliability of research is defined as scientific deception (Kansu \& Ruacan, 2002). There are many reasons why individuals engage in scientific deception. Academic promotions, job applications, scientific fund applications and concerns regarding academic prestige have pressured individuals to publish increasingly more scientific papers. There are papers and studies of all natures, including studies that were conducted entirely in good faith but incorrectly, as well as studies that include deliberate deceptions to gain individual or institutional benefits (Ruacan, 2003).

Major scientific deceptions are classified as follows: inventing (fabrication), warping (falsification) information and data, and stealing data from other individuals (plagiarism) (Ülman, 2006). Furthermore, the replication of publication, multi-publication (duplication), slicing, segmented publication (salamisation), slanted or missing references, disrespect for human-animal ethics, partial selection of sources, partial publication, and the utilisation of author names in nonauthentic ways are also considered scientific deception (Kansu \& Ruacan, 2002; Ülman, 2006; İnci, 2009). These dubious actions are consciously performed by authors with the intention of deception. If research is conducted without substantial knowledge regarding research planning, appropriate research methods, or analysis of results, this approach is considered undisciplined research, and the related scientific deceptions are assumed to occur in good faith. It is supposed that with the appropriate education, these researchers can be scientifically retrained (Kansu \& Ruacan, 2002).

When behaviours against scientific research ethics emerge and are proven, penal sanctions are enforced. Opinions vary regarding whether different quantities of plagiarized study reflect different intensity levels of academic fraud, and with regard to criteria for what creates plagiarism (Roig, 2001). For example, in Turkey, under the head of the 7th items of the Inter-university Board Regulation on Associate Professorship Appointments, the application of an associate professor candidate, who is the subject of a plagiarism claim, falls into abeyance until a decision has been made regarding the claim (YÖK, 2015). Moreover, the 11th items of the Disciplinary Code of Higher Education Institutions states that any instructor "showing somebody else's scientific work or a part of it without giving appropriate reference or as if it is their own work" is punished with "dismissal of university instruction profession" (YÖK, 1982). In universities increasing number of complaints from hard-working students who see fellow students willing to ignore ethical codes only to be awarded for their behavior (Martin et al., 2009). 
The number of studies regarding the amount of information related to ethical problems encountered during scientific studies in Turkey is very low. In this study, postgraduate students who receive their education in physical education and sports fields were assessed regarding their views of non-ethical behaviours in the framework of scientific research ethics. Furthermore, the prevalence of scientific deception in scientific publications was assessed and subsequently measured.

In this context, the study aimed to examine postgraduate students were assessed regarding their views of non-ethical behaviours in the framework of scientific research ethics in terms of some variables (occupation, status of publishing scientific work, status of education)

Answers to questions provided below were sought in line with this purpose:

1. What are the views of postgraduate students regarding research ethics?

2. Do views of students postgraduate students regarding research ethics show significant differences based on independent variables (occupation, status of publishing scientific work, status of education)

\section{Methods}

\subsection{Participants}

This research was conducted using descriptive methods. The group under examination consisted of 112 randomly chosen students who pursued their postgraduate degree in the physical education and sports fields in Turkey. The participants were divided into five age categories: 25 years old or younger $(\mathrm{n}=21 ; 18.8 \%), 26-30$ years old $(\mathrm{n}=54 ; 48.2 \%), 31-35$ years old $(n=28 ; 25 \%), 36-40$ years old $(n=7 ; 6.2 \%)$ and older than 40 years $(n=2 ; 1.8 \%)$. The participants comprised 43 females $(38.4 \%)$ and 69 males (61.4\%); when the education state was analysed, 67 participants $(59.8 \%)$ were pursuing master degrees, and $45(40.2 \%)$ were pursuing doctoral studies. Regarding student occupations, 33 participants worked as academic staff, and 79 worked as non-academic professionals. In addition, 69 students $(61.6 \%)$ had never taken research ethics lectures, whereas $43(38.4 \%)$ had taken research ethics lectures. When the scientific paper publication status of the students was analysed, 55 students $(49.1 \%)$ had published scientific papers, whereas $57(50.9 \%)$ had not published. When the postgraduate students were analysed, 50 students $(44.6 \%)$ were enrolled in physical education and sports programs, $11(9.8 \%)$ were physical education teachers, $15(13.4 \%)$ were sport managers, $26(23.2 \%)$ were undergoing kinesis training, $3(2.7 \%)$ were involved in psychosocial areas, $2(1.8 \%)$ were physical educators and sports scientists, and $5(4.5 \%)$ were involved in sport and health activities.

\subsection{Ethical clearance}

The required applications were submitted to the universities and the necessary permission was obtained. Before the study was conducted, a short description was provided to the entire participants. Participants were obtained permission with informed consent form.

\subsection{Measures}

The scale questions were substantially prepared by benefiting from the works of Köklü (2003). Twenty-one items were identically replicated, 4 items were modified, and 7 new items were added to the scale by the authors. The scale options and relevant scores were as follows: I have no idea ( 1 points), Never ( 2 points), Occasionally ( 3 points), Frequently ( 4 points), and 
Always (5 points). In addition, on a separate form, the research group was asked to answer whether the 32 items in the scale were (1) or were not (2) in accord with research ethics.

\subsection{Statistical analysis}

The validity and reliability were assessed in the framework of this study. Item total correlation and factor analyses were performed for the construct validity of the assessment tool. The Alpha Coefficient was assessed for the reliability. A threshold value of $r=0.30$ between the items was used to determine whether an item should be included in the scale. No item was excluded from the scale because of this inclusion criteria. The item total correlation values of the items situated at the scale varied between .47 and .77 .

Prior to the factor analysis, to determine the conformity of the data, the Kaiser-Meyer-Olkin (KMO) value was identified as .89. This value indicates that the conformity of the data with the factor analysis is perfect (Sipahi et al., 2010). Furthermore, the Barlett test was conducted for the factor analysis of all items in the scale, and a $[2.690(p<0.001)]$ result was obtained. The KMO and Barlett test results justified that the factor analyses can be performed with these data. A factor loading value greater or equal to .45 is a good choice of selection (Büyüköztürk, 2011). When deciding which items should be included in the scales, factor loading values greater or equal to .45 were set as the standard. No item was excluded from the scale because of this standard. The factor loading values of the 32 items in the scale varied between .49 and .79 . According to the factor analysis, $45.12 \%$ of the total variance in which the scale is one dimension was explained. The Alpha Coefficient was calculated for the scale reliability, and a value of .96 indicated that the scale is valid and reliable.

The frequencies and percentages were analysed. The Shapiro-Wilk test indicated that the data did not exhibit a normal distribution; thus, the results were analysed with a non-parametric Mann-Whitney U test.

\section{Results}

The mean values, standard deviations, and score order are provided in Table 1 in relation to the level of occurrence of non-ethical behaviours of the postgraduate students in scientific research and the percentage of individuals who disapprove of these behaviours. Thus, "writing more than one article using the same data" $(M=2.58)$ and "citing without providing a reference" $(M=2.38)$, "reporting findings that are only consistent with expectations" $(M=2.24)$, "publishing someone else's ideas without providing references as if they are one's own" $(M=2.18)$, "presenting the same research in more than one conference or symposium" $(M=2.18)$, and "publishing the same research in more than one journal" $(M=2.17)$ are reported as the most observed behaviours in scientific research. In contrast, "concealing research findings that harm participants" ( $M=1.45)$ and "exercising hidden experimental treatment on participants" $(M=1.17)$ are identified as the least identified behaviours in scientific research.

According to Table 1, when the viewpoints of the postgraduate students regarding research ethics and behaviours that they found contrary to ethics were examined, "presenting falsified research findings" and "publishing someone else's research with own name" were identified as non-ethical by $100 \%$ of the participants, which indicates the most affirmed non-ethical behaviours by the participants. "Presenting falsified research findings" is identified as non-ethical by $28.2 \%$ of the participants, "publishing the same research in different languages" was identified as non-ethical by $45.5 \%$, "writing more than one article using the same data" was identified as non-ethical by $75 \%$, "presenting the same research in more than one conference or symposium" was identified as non-ethical by $77.7 \%$, "citing without providing a reference" was identified as 
Koçak, F., \& Özbek, O. (2016). Views of postgraduate students regarding research ethics in Turkey. Journal of Human Sciences, 13(2), 3560-3570. doi:10.14687/ihs.v13i2.3780

non-ethical by $97.3 \%$, "presenting research findings in multiple publications in such a way research is disintegrated" was identified as non-ethical by $92.9 \%$, "using someone else's quantification approach without permission" was identified as non-ethical by $92 \%$, and "using someone else's quantification approach without providing a reference" was identified as nonethical by $96.4 \%$ of the participants.

Table 1: Mean values, standard deviations, and score orders

\begin{tabular}{|c|c|c|c|c|}
\hline Items & $\begin{array}{c}\text { Percentage } \\
\text { of individuals } \\
\text { who characterise } \\
\text { behaviour as } \\
\text { non-ethical }\end{array}$ & $M$ & $S D$ & $\begin{array}{l}\text { Score } \\
\text { order }\end{array}$ \\
\hline 1.Fabricating data at desk without conducting research & 97.3 & 1.91 & 1.32 & 15.5 \\
\hline 2.Reporting falsified research data & 28.2 & 1.86 & 1.23 & 18 \\
\hline $\begin{array}{l}\text { 3.Publishing someone else's ideas without providing references } \\
\text { as if they are one's own }\end{array}$ & 96.4 & 2.18 & 1.25 & 4.5 \\
\hline 4. Breaking a confidentiality agreement & 96.4 & 1.74 & 1.29 & 23 \\
\hline 5.Destroying data that are contradictory to researcher & 97.3 & 1.91 & 1.35 & 15.5 \\
\hline 6.Providing false information regarding the research method & 99.1 & 1.61 & 1.17 & 26.5 \\
\hline $\begin{array}{l}\text { 7.Deliberatively using improper statistical techniques when } \\
\text { analysing research data }\end{array}$ & 98.2 & 1.64 & 1.34 & 25 \\
\hline $\begin{array}{l}\text { 8.Using a quantification tool without demonstrated credibility } \\
\text { and legitimacy }\end{array}$ & 93.8 & 1.77 & 1.22 & 22 \\
\hline $\begin{array}{l}\text { 9.Precluding repeatability of research method by deficient } \\
\text { reporting }\end{array}$ & 97.3 & 1.67 & 1.20 & 24 \\
\hline $\begin{array}{l}\text { 10.Reporting findings that are only consistent with } \\
\text { expectations }\end{array}$ & 96.4 & 2.24 & 1.37 & 3 \\
\hline 11.Citing without providing a reference & 97.3 & 2.38 & 1.33 & 2 \\
\hline 12.Writing more than one article using the same data & 75.0 & 2.58 & 1.44 & 1 \\
\hline 13.Forcing other individuals to participate in research & 95.5 & 2.09 & 1.42 & 10 \\
\hline $\begin{array}{l}\text { 14.Including a reference that is not cited in the bibliography } \\
\text { section of the research report }\end{array}$ & 94.6 & 2.04 & 1.42 & 12 \\
\hline 15.Publishing the same research in more than one journal & 77.7 & 2.17 & 1.40 & 6 \\
\hline 16.Presenting falsified research findings & 100 & 1.83 & 1.26 & 21 \\
\hline 17.Exercising hidden experimental treatment on participants & 94.6 & 1.17 & 1.05 & 32 \\
\hline 18.Concealing research findings that harm participants & 95.5 & 1.45 & 1.26 & 31 \\
\hline $\begin{array}{l}\text { 19.Adding individuals whose contributions are incompatible } \\
\text { with authorship as co-authors to the research report }\end{array}$ & 95.5 & 2.07 & 1.48 & 11 \\
\hline $\begin{array}{l}\text { 20.Reasonless or inappropriate changing of the order of } \\
\text { research authors }\end{array}$ & 98.2 & 1.93 & 1.50 & 14 \\
\hline 21.Using another researcher's data without permission & 93.8 & 1.84 & 1.46 & 20.5 \\
\hline $\begin{array}{l}\text { 22. Not stating institutional or organisational support on } \\
\text { publications that contain findings of supported studies }\end{array}$ & 97.3 & 1.51 & 1.28 & 28 \\
\hline 23.Hiding aim of researcher & 98.2 & 1.49 & 1.10 & 29 \\
\hline $\begin{array}{l}\text { 24.Publishing an article by translating it without the permission } \\
\text { of its author }\end{array}$ & 97.3 & 1.84 & 1.42 & 20.5 \\
\hline $\begin{array}{l}\text { 25.Using someone else's quantification approach without } \\
\text { permission }\end{array}$ & 92.0 & 2.11 & 1.48 & 8 \\
\hline $\begin{array}{l}\text { 26.Using someone else's quantification approach without } \\
\text { providing a reference }\end{array}$ & 96.4 & 1.89 & 1.30 & 17 \\
\hline $\begin{array}{l}\text { 27.Presenting the same research in more than one conference } \\
\text { or symposium }\end{array}$ & 68.8 & 2.18 & 1.50 & 4.5 \\
\hline $\begin{array}{l}\text { 28. Including supportive data only while comparing own data } \\
\text { with data from other studies }\end{array}$ & 92.0 & 2.10 & 1.37 & 9 \\
\hline $\begin{array}{l}\text { 29. Testing, experimenting or measurement on children } \\
\text { without parental permission }\end{array}$ & 97.3 & 1.46 & 1.28 & 30 \\
\hline
\end{tabular}


Koçak, F., \& Özbek, O. (2016). Views of postgraduate students regarding research ethics in Turkey. Journal of Human Sciences, 13(2), 3560-3570. doi:10.14687/ihs.v13i2.3780

\begin{tabular}{|c|c|c|c|c|}
\hline 30.Publishing someone else's research with own name & 100 & 1.61 & 1.25 & 26.5 \\
\hline $\begin{array}{l}\text { 31.Presenting research findings in multiple publications in such } \\
\text { a way that research is disintegrated }\end{array}$ & 92.9 & 1.99 & 1.41 & 13 \\
\hline 32.Publishing the same research in different languages & 45.5 & 2.16 & 1.44 & 7 \\
\hline
\end{tabular}

No significant difference was identified as a result of the Mann-Whitney $U$ test regarding the views of postgraduate students on the level of occurrence of behaviours that are against research ethics, according to the variables of gender and their status of participation in a research ethics lecture.

A significant difference in one item was identified as a result of the Mann-Whitney $U$ test, i.e., individuals who do or do not work as academic staff. In addition, the Mann-Whitney U test indicated the views regarding the item "presenting research findings in multiple publications in such a way that research is disintegrated" were significantly different $(\mathrm{U}=990.5, p<.05)$. When the rank averages are considered, the postgraduate students who worked as academic staff indicated that the level of occurrence of "presenting research findings in multiple publications in such a way that research is disintegrated" is higher with respect to the students who are not academic staff (Table 2).

Table 2: Results of the Mann-Whitney $U$ test regarding the views of postgraduate students with respect to occupation variable

\begin{tabular}{|c|c|c|c|c|c|c|}
\hline Items & Occupation & $M$ & $\begin{array}{c}\text { Mean } \\
\text { rank }\end{array}$ & $\begin{array}{c}\text { Sum of } \\
\text { ranks }\end{array}$ & $\boldsymbol{U}$ & $P$ \\
\hline \multirow{2}{*}{$\begin{array}{l}\text { Presenting research findings in } \\
\text { multiple publications in such a } \\
\text { way that research is } \\
\text { disintegrated }\end{array}$} & Academic staff (1) & 2.39 & 65.98 & 2177.5 & \multirow[b]{2}{*}{990.5} & \multirow[b]{2}{*}{$.042^{*}$} \\
\hline & Non-academic staff (2) & 1.82 & 52.54 & 4150.5 & & \\
\hline
\end{tabular}

Significant differences were identified as a result of the Mann-Whitney $\mathrm{U}$ test regarding the views of the postgraduate students who do and do not publish scientific work on the level of occurrence of behaviours against research ethics. Regarding the Mann-Whitney U test performed on the views related to "publishing an item by translating it without the permission of its author", a significant difference was identified $(\mathrm{U}=1.15, p<.05)$. When the rank averages are considered, the postgraduate students who work as academic staff indicated that the level of occurrence of "publishing an article by translating it without permission of its author" is higher with respect to the students who do not work as academic staff.

Regarding the Mann-Whitney U test on views related to the item "using someone else's quantification approach without providing a reference", a significant difference was identified $(\mathrm{U}=1.13, p<.05)$. When the rank averages are considered, the postgraduate students who publish scientific work indicated that the level of occurrence of "using someone else's quantification approach without providing a reference" behavior is higher with respect to the students who do not publish scientific work. Regarding the Mann-Whitney $U$ test on the views related to the item "presenting research findings in multiple publications in such a way that research is disintegrated", a significant difference was identified (U=1.17, $p<.05)$. When the rank averages are considered, the postgraduate students who do not publish scientific work indicated that the level of occurrence of "presenting research findings in multiple publications in such a way that research is disintegrated" is higher with respect to the students who publish scientific work (Table 3). 
Significant differences were identified as a result of the Mann-Whitney $U$ test regarding the views of the doctorate and master students. Regarding the Mann-Whitney $U$ test of the views related to the item "citing without providing a reference", a significant difference was identified $(\mathrm{U}=1.18, p<.05)$. When the rank averages are considered, the doctorate students indicated that the level of occurrence of "citing without providing a reference" is higher with respect to the master students. Regarding the Mann-Whitney U test on the views related to the item "reasonless or inappropriate changing of the order of research authors", a significant difference was identified $(\mathrm{U}=1.16, p<.05)$.

Table 3: Results of the Mann-Whitney $U$ test regarding the views of the postgraduate students with respect to the status of publishing scientific work

\begin{tabular}{|c|c|c|c|c|c|c|}
\hline Items & $\begin{array}{l}\text { Status of } \\
\text { Publishing } \\
\text { Scientific } \\
\text { Work }\end{array}$ & $M$ & $\begin{array}{l}\text { Mean } \\
\text { Rank }\end{array}$ & $\begin{array}{l}\text { Sum of } \\
\text { Ranks }\end{array}$ & $\mathbf{U}$ & $p$ \\
\hline \multirow{2}{*}{$\begin{array}{l}\text { Publishing an article by translating it without the } \\
\text { permission of its author }\end{array}$} & $\begin{array}{c}\text { Does not } \\
\text { publish(1) }\end{array}$ & 2.18 & 63.96 & 3518 & \multirow[b]{2}{*}{1.15} & \multirow[b]{2}{*}{$.015^{*}$} \\
\hline & Publishes(2) & 1.52 & 49.30 & 2810 & & \\
\hline \multirow{2}{*}{$\begin{array}{l}\text { Using someone else's quantification approach } \\
\text { without providing a reference }\end{array}$} & $\begin{array}{l}\text { Does not } \\
\text { publish(1) }\end{array}$ & 2.29 & 64.43 & 3543 & \multirow{2}{*}{1.13} & \multirow{2}{*}{$.009 *$} \\
\hline & Publishes(2) & 1.94 & 48.85 & 2784 & & \\
\hline \multirow{2}{*}{$\begin{array}{l}\text { Presenting research findings in multiple } \\
\text { publications in such a way that research is } \\
\text { disintegrated }\end{array}$} & $\begin{array}{l}\text { Does not } \\
\text { publish(1) }\end{array}$ & 1.67 & 49.27 & 2710 & \multirow{2}{*}{1.17} & \multirow{2}{*}{$.018^{*}$} \\
\hline & Publishes(2) & 2.29 & 63.47 & 3618 & & \\
\hline $\mathrm{n}_{1}=55$ & $\mathrm{~N}=112$ & & $b<.05$ & & & \\
\hline
\end{tabular}

When the rank averages are considered, the doctorate students indicated that the level of occurrence of "reasonless or inappropriate changing of the order of research authors" is higher with respect to the master students (Table 4).

Table 4: Results of the Mann-Whitney $U$ test regarding the views of the postgraduate students with respect to the status of the education variable

\begin{tabular}{|c|c|c|c|c|c|c|}
\hline Items & $\begin{array}{c}\text { Status of } \\
\text { Education }\end{array}$ & $M$ & $\begin{array}{l}\text { Mean } \\
\text { Rank }\end{array}$ & $\begin{array}{l}\text { Sum of } \\
\text { Ranks }\end{array}$ & $\mathbf{U}$ & $p$ \\
\hline \multirow{2}{*}{ Citing without providing a reference } & Master(1) & 2.19 & 51.67 & 3462.0 & & \\
\hline & Doctorate(2) & 2.66 & 63.69 & 2866.0 & 1.18 & $.049 *$ \\
\hline \multirow{2}{*}{$\begin{array}{l}\text { Reasonless or inappropriate changing of } \\
\text { the order of research authors }\end{array}$} & Master(1) & 1.68 & 51.44 & 3446.5 & & \\
\hline & Doctorate(2) & 2.31 & 64.03 & 2881.5 & 1.16 & $.040 *$ \\
\hline
\end{tabular}

\section{Discussion}

Scientific deception is deliberately performed for a variety of reasons, and it can emerge because of improperly presented research methods. Because of the challenges regarding data collection, the number of works in the literature regarding scientific deception is very limited. Fanelli (2009) concluded that when data are collected via email, the ratio of individuals who accept that they perform scientific deception is lower than individuals who provide direct answers. 
"Writing more than one article using the same data", "citing without providing a reference", "reporting findings that are only consistent with expectations", "publishing someone else's ideas without providing references as if they are one's own", "presenting the same research in more than one conference or symposium", and "publishing the same research in more than one journal" are the most identified non-ethical behaviours in scientific research. May et al.'s (1998) study of 36 British authors indicated that 17 of the authors had heard about non-ethical behaviour in scientific research within the previous 4 years. The findings of May et al. (1998) also support our study. Sisti's (2007) study on 160 high school students, approximately $35 \%$ of respondents indicated that they had directly copied and pasted material into an assignment, without citation. Of these students, approximately $46 \%$ indicated they considered it plagiarism or cheating. Hayes and Introna's (2005) study on 46 students who are Master of Science (MSc) students from different country at Lancaster University Management School, described that many international students believe cheating is incorrect, but they still apply in it in quite a prevalent way. Within Köklü's (2003) work, $22.9 \%$ of academics indicated that research ethics had been violated very few times, whereas $37.1 \%$ indicated occasionally and $40 \%$ indicated very frequently. Meyer and Macmahon (2004) evaluated 30 behaviours encountered during studies conducted through surveys in their study regarding 70 experienced and 106 beginning academics. "Making changes to the order of authors of research inappropriately and in a non-realistic way", "trying to learn a panel member's identity who presents negative views", and "publishing someone else's ideas without providing references as if they are one's own" are evaluated as non-ethical behaviours.

In this study, "presenting the same research in more than one conference or symposium", "publishing the same research in different languages", "writing more than one article using the same data" and "publishing the same research in more than one journal" are not evaluated as non-ethical behaviours per some participants. The lack of adequate information in postgraduate students regarding research ethics can be the reason for them not acknowledging these nonethical behaviours, which can also be referred to as duplications. "Citing without providing a reference", "presenting falsified research findings", "presenting research findings in multiple publications in such a way that research is disintegrated", "using someone else's quantification approach without permission", and "using someone else's quantification approach without providing a reference" were identified as non-ethical by almost all participants. Supporting results have been obtained in similar studies. For example, according to Erdemir et al., (2004), "citing without providing a reference" was detected as non-ethical against occupational ethics. In Civaner et al.'s (2000) study, "gift authorship" and "publication of falsified research findings" were identified by the majority of instructors as non-ethical behaviours against publication ethics, whereas "publication of research piece by piece" and "honorary authorship" were not perceived as non-ethical per publication ethics. Stephens et al.'s study (2007) also performed between 1,305 students in two universities. The results showed that students used conventional means more often than digital means on copying homework. All participants indicated that "presenting falsified research findings and publishing someone else's research with own name" are nonethical behaviours. Plagiarism and falsification, which require the imposition of heavy sanctions (YÖK, 1982) among non-ethical behaviours, were indicated as non-ethical behaviours by all participants, which is a positive status. In contrast to research findings in a study of academics by Köklü (2003), changing research findings, destroying data that are contradictory with researchers, providing false information on research methods, citing/picking without providing a reference, and the addition of individuals whose contributions are incompatible with authorship as coauthors to the research have been identified as non-ethical behaviours by all participants.

In various studies that examined non-ethical behaviours against research ethics, participants have indicated that they either performed scientific deception or witnessed it. For example, in a 
study by Gardner et al. (2005) of 322 researchers in the field of medicine, 1\% of the writers indicated that they performed scientific deception, whereas $5 \%$ stated they had encountered data fabrication or scientific deception in the previous 10 years, and $17 \%$ had personally witnessed an action of scientific deception. In Fanelli's (2009) meta-analysis of 21 scientific articles, $1.97 \%$ of the scientists indicated that they had fabricated or falsified data, and 33\% used research methods that are open to disputes. In Rankin and Esteves's (1997:270-276) research regarding 88 coordinators and managers at the master and doctorate levels, which was conducted to identify the perceptions of nurses regarding scientific deception, $45.5 \%$ of the participants indicated that they rarely encounter data fabrication in scientific studies, $27.2 \%$ believe that they have similar events in their institutions, and 33.2\% stated they believe research data are falsified. In research financed by the UK Department of Health and Human Services (DHHS), which was undertaken by Titus et al. (2008), 2212 scientists participated in the DHHS's studies; 59.7\% of the scientists stated they encountered data fabrication and falsification, $46.3 \%$ encountered plagiarism, and $4 \%$ encountered other types of scientific deception in their departments in the previous 3 years. Hu and Lei (2015) found significant main influence of year of study on different attitudes toward plagiarism. Third-year students were meaningful more tolerant against plagiarism than were first year students.

Graduate students who work as academic staff indicated that the level of occurrence of "presenting research findings in multiple publications in such a way that research is disintegrated" is higher with respect to the students who do not work as academic staff. Conditions of academic promotion may have forced individuals who are under "publish or perish" pressure. Doctorate students who do not publish scientific work indicated that the level of occurrence of "Publishing an article by translating it without permission of its author" is higher with respect to the students who publish scientific work. Doctorate students who do not publish scientific work indicated that the level of occurrence of "Presenting research findings in multiple publications in such a way that research is disintegrated" is higher with respect to the students who publish scientific work. According to Sümer (1998), presenting integrated data collected from the same sample in parts results from the struggle to publish more scientific work rather than contributing to the scientific literature.

The level of occurrence of the "citing without providing a reference" behaviour in the scientific research of doctorate students was greater than the master students. The level of occurrence of the "reasonless or inappropriate changing of the order of research authors" behaviour in the scientific research of doctorate students was greater than the master students. This situation may have originated because doctorate students have observed more individuals in their environment who publish scientific work.

\section{Conclusion}

As a result, more non-ethical behaviours against research ethics will be presented in the future. Academic incompetency, the lack of work discipline or bad habits, personal ambitions, and rashness in academic promotion may drag individuals towards non-ethical behaviours. If these causes are reduced to a minimum level, non-ethical behaviours would also decrease. In addition to legal sanctions, scientific research education should be provided to undergraduate and postgraduate students to prevent scientific deception in scientific research. 
Koçak, F., \& Özbek, O. (2016). Views of postgraduate students regarding research ethics in Turkey. Journal of Human Sciences, 13(2), 3560-3570. doi:10.14687/ihs.v13i2.3780

\section{References}

Belsey. A, Chadwick, R. (1998). Medya ve Gazetecilikte Etik Sorunlar, Nurçay Türkoğlu (çev.), İstanbul: Ayrınt1 Yayınları.

Büyüköztürk, S. (2011). Sosyal Bilimler için Veri Analizi El Kitabı İstatistik, Araștırma Deseni SPSS Uygulamalar ve Yorum. Ankara: Pegem Akademi Yayıncilik.

Civaner M, Demiral Y, Şemin S, Amato Z. (2000). Dokuz Eylül Üniversitesi Tip Fakültesi'nde çalışan öğretim elemanlarının yayın etiği konusundaki bilgi ve görüşleri. Dokuz Eylül Üniversitesi Thp Fakültesi Dergisi, 14(2):161-9.

Erdemir, K N., Öz, M., Güleç, S. (2004). Analysis of attitudes of academicians towards scientific morality: Empirical study on Selcuk University Karaman Campus. 3rd National Congress on Information, Economy and Management. Eskişehir, Turkey, 25-26 October, 69-78.

Fanelli, D. (2009). How many scientists fabricate and falsify research? A systematic review and meta-analysis of survey data. PLoS One, 4(5), 1-11. doi:10.1371/journal.pone.0005738

Gardner, W., Lidz, C.W., Hartwig, K.C. (2005). Authors' reports about research integrity problems in clinical trials. Contemporary Clinical Trials, 26, 244-251. doi:10.1016/j.cct.2004.11.013

Hatcher, T. (2004). Environmental ethics as an alternative for evaluation theory in for profit business context. Evaluation and Program Planning, 27, 357-363. doi:10.1016/j.evalprogplan.2004.04.009

Hayes, N., Introna, L.D. (2005). Cultural values, plagiarism, and fairness: When plagiarism gets in the way of learning, Ethics and Behavior, 15(3), 213-231. doi:10.1207/s15327019eb1503_2

Hu, G., Lei, J. (2015) Chinese university students' perceptions of plagiarism, Ethics and Behavior, 25(3), 233-255. doi: 10.1080/10508422.2014.923313

Inci, O. (2009). Bilimsel yaym etiği ilkeleri, yamltmalar yanultmalar önlemeye yönelike öneriler. Sağlık Bilimlerinde Süreli Yayıncllık 7. Ulusal Sempozyum Bildirileri, 20 Kasım, Ankara: TÜBİTAK ULAKBIM, 69-89. Retreived from: http://uvt.ulakbim.gov.tr/tip/sempozyum7/inci.pdf

Erzan, A., Irzık, G., Kansu, E., Ruacan, Ş., Tekcan, A.İ., Tolun, A., Yılmaz, Y. (2008) Bilim Etiği El Kitab1, Ankara: TÜBA Yayınları.

Kansu, E., Ruacan, Ş. (2002). Bilimsel Yanıltmanın Günümüzdeki Durumu: Türleri, Nedenleri, Önlenmesi ve Cezalandirilmas1 Archives of the Turkish Society of Cardiology, 30 (12), 763-767.

Köklü, N. (2003). Akademisyenlerin araştırma etiği konusundaki görüşleri. Eğitim Bilimleri ve Uygulama. 2(4), 137-151.

Martin, D.E., Roa, A., Sloan L.R. (2009). Plagiarism, integrity, and workplace deviance: a criterion study, Ethics and Behavior, 19(1), 36-50. doi:10.1080/10508420802623666

May, C., Campbell, S., Doyle, H. (1998). Research misconduct: a pilot study of British addiction researchers. Addiction Research. 6(4), 371-373. doi: 10.3109/16066359808993312

Meyer, M.J., Mcmahon, D. (2004). An examination of ethical research conduct by experienced and novice accounting academics. Issues in Accounting Education, 19(4), 413-442. doi: 10.2308/iace.2004.19.4.413

Ongun M.T. (2006). Araştırma ve yayın etiğgi, Sosyal Bilimlerde Süreli Yayıncılık, I. Ulusal Kurultay Bildirileri, 2-3 Kasım, Ankara: TUBİTAK, ULAKBİM, 89-93. Retrieved from http://uvt.ulakbim.gov.tr/sbvt/kurultay1.pdf?ref=Sawos.Org\#page=77

Pieper, A. (1999). Etiğge Girişs,. Translated by Atayman, V., Gönül S. Istanbul: Ayrıntı Publications. 
Koçak, F., \& Özbek, O. (2016). Views of postgraduate students regarding research ethics in Turkey. Journal of Human Sciences, 13(2), 3560-3570. doi:10.14687/ihs.v13i2.3780

Rankin, M., Esteves, M. D. (1997). Perceptions of scientific misconduct in nursing. Nursing Research, 46(5), 270-276. doi: 10.1097/00006199-199709000-00005

Roig, M. (2001). Plagiarism and paraphrasing criteria of college and university professors. Ethics and Behavior, 11, 307-323.

Ruacan Y. (2003). Bilimsel araştırma ve yayınlarda etik ilkeler, Sağlık Bilimlerinde Süreli Yayıncılık, I. Ulusal Sempozyumu, 28. Mart, Ankara: TÜBİTAK, ULAKBİM. 1-7. Retrieved from http://uvt.ulakbim.gov.tr/tip/sempozyum1/sruacan2.pdf

Sipahi, B., Yurtkoru S.E., Çinko, M. (2010). Sosyal Bilimlerde SPSS'le Veri Analið̌, 3. Bask1, Istanbul: Beta Yayınları.

Sisti D.A. (2007). How do high school students justify internet plagiarism? Ethics and Behavior, 17(3), 215-231. doi:10.1080/10508420701519163

Stephens, J.M., Young, M.F., Calabrese, T.H. (2007). Does moral judgment go offline when students are online? A comparative analysis of undergraduates' beliefs and behaviours related to conventional and digital cheating. Ethics and Behavior, 17, 233-254. doi:10.1080/10508420701519197

Sümer, C. (1998). Türkiye'de psikoloji uygulama, araştırma ve yayımlarında etik ilkeler: Tartısma I. Türk Psikoloji Dergisi, 13, 77-79.

Tepe, H. (2000). Etik ve Meslek Etikleri, Ankara: Türkiye Felsefe Kurumu Yayınları.

Titus, S.L., Wells, J.A. Rhoades L.J. (2008). Repairing research integrity. Nature, 453, 980-982. doi:10.1038/453980a

TUBA. (2002). Bilimsel Arastırmada Etik ve Sorunlar II, Türkiye Bilimler Akademisi, Bilim Etiği Komitesi, Ankara: Tübitak Matbaas1.

Ülman Y.I. (2006). Bilimsel bilgi üretiminde yayn etiği (Örnekleriyle bilimsel yamltma türleri), Tibbi Yayın Hazırlama Kuralları ve Yayın Etiği ed. H. Yazıc1, M. Şenocak, İ.Ü. Cerrahpaşa Tıp Fakültesi Sürekli Tıp Eğitimi Programı, İstanbul: Nobel Yayınları.

Uluoğlu, C. (2009). Araşstrma etiğ̈i, Sağlık Bilimlerinde Süreli Yayıncılık 7.Ulusal Sempozyum Bildirileri, 20 Kasım, Ankara: Ankara: TÜBİTAK, ULAKBİM., 47-52. Retreived from: http://uvt.ulakbim.gov.tr/tip/sempozyum7/uluoglu.pdf

Uzun, E., Karakuş, T., Kurşun, E., Karaaslan, H. (2007). Öğrenci gözzülle aşırma (intibal): neden ve çö̊üm önerileri. Akademik Bilişim, 2007 Bildiriler Kitapçığ1, 31 Ocak -2 Şubat, Kütahya, Türkiye, 183-188.

Yannacone, J.V. (1999). Science, ethics, and scientific ethics in the modern world. Environmental Geosciences, 6(4), 164-171. doi: 10.1046/j.1526-0984.1999.64002.x

YÖK (1982). Ÿ̈ßksekögretim Kurumlar Yönetici, Ögrretim Eleman ve Memurlarn Disiplin Yönetmeliği, Retrieved from: http://www.yok.gov.tr/web/guest/icerik//journal_content/56_INSTANCE_rEHF8BIsfYRx/10279/17706

YÖK (2015). Doçentlik Sinav Yönetmeliğg, $\quad$ Retrieved from http://www.resmigazete.gov.tr/eskiler/2015/02/20150207-13.htm 